\title{
Gemcitabine-Releasing Intravesical System
}

National Cancer Institute

\section{Source}

National Cancer Institute. Gemcitabine-Releasing Intravesical System. NCI Thesaurus.

Code C150807.

A controlled-release intravesical system consisting of a small flexible tube-like device with a solid core composed of gemcitabine, a broad-spectrum antimetabolite and deoxycytidine analogue, with antineoplastic activity. Upon placement of the gemcitabinereleasing intravesical system (GemRIS) into the bladder, gemcitabine is gradually and continuously released from the system over an extended period of time before being removed from the bladder. Upon release, gemcitabine is converted into the active metabolites difluorodeoxycytidine diphosphate (dFdCDP) and difluorodeoxycytidine triphosphate (dFdCTP) by deoxycytidine kinase. dFdCT P competes with deoxycytidine triphosphate (dCTP) and is incorporated into DNA, resulting in premature termination of DNA replication and the induction of apoptosis of bladder tumor cells. In addition, $\mathrm{dFdCDP}$ inhibits ribonucleotide reductase (RNR) and reduces the deoxynucleotide pool available for DNA synthesis. 